\title{
Prevalence of overweight, obesity, physical activity and tobacco use in Argentine youth: Global School-Based Student Health Survey and Global Youth Tobacco Survey, 2007-2012
}

\author{
Daniel Ferrante, M.D. ${ }^{a}$, Bruno Linetzky, M.D. ${ }^{a}$, Miguel Ponce, B.S. ${ }^{a}$, \\ Lucila Goldberg, B.S. ${ }^{a}$ Jonathan Konfino, M.D. ${ }^{a}$, and Sebastián Laspiur, M.D. ${ }^{a}$
}

\begin{abstract}
Introduction. In 2007 and 2012, the GlobalSchoolBased Student Health Survey (GSHS) and the Global Youth Tobacco Survey (GYTS) were implemented to estimate the prevalence of risk behaviors and protection factors among 13 to 15 year-old adolescents.
\end{abstract}

Objective. To assess changes in dietary, body weight, tobacco and physical activity indicators in the past five years.

Population and Methos. Cross-sectional study. A randomized, two-stage sampling with 600 schools selected at a national level was used. Students from randomly selected courses were invited to answer a self-administered questionnaire (either the GSHS or the GYTS).

Results. In 2012, the GSHS was completed by 20 697 students from 544 schools, while the GYTS was completed by 2062 students from 73 schools. Between 2007 and 2012, overweight and obesity prevalence significantly increased (overweight: $24.5 \%$ in $2007,28.6 \%$ in 2012 ; obesity $4.4 \%$ in 2007 , $5.9 \%$ in 2012), while the consumption of sugarsweetened beverages and fast food remained high. A slight improvement was observed in the level of physical activity $(12.7 \%$ in 2007 , $16.7 \%$ in 2012), although it remains below what is recommended. The prevalence of tobacco use was reduced $(24.5 \%$ in $2007,19.6 \%$ in 2012$)$, but access to tobacco products and exposure to secondhand smoke remains high in public places, including schools.

Conclusions. The spread of the overweight and obesity epidemic calls for a need to consolidate actions tending towards a healthy diet and physical activity. Despite a decrease in the prevalence of tobacco use, it is necessary to continue strengthening tobacco control actions. Key words: youth behavior, prevalence, noncommunicable diseases, risk factors, public policies, health surveys.

http:/ /dx.doi.org/10.5546/aap.2014.eng.496

Funding:

Ministry of Health.

E-mail Address:

Daniel Ferrante, M.D.:

dferrante@msal.gov.ar

Conflict of Interest: None.

Received: 12-3-2014 Accepted: 16-6-2014 the total burden of disease in adults are associated with conditions or behaviors that started during adolescence. ${ }^{1,2}$

Most of the burden of disease is related to non communicable diseases, which account for $63 \%$ of deaths in Argentina. ${ }^{3}$ Most of the risk attributed to these diseases is connected with an unhealthy diet, tobacco use and lack of physical activity. ${ }^{4}$

Overweight and obesity are increasing globally, especially in developing countries. A higher consumption of processed food and sugar-sweetened beverages and the progressive reduction of physical activity are some of the factors that contribute to such increase. ${ }^{5}$

Most smokers start during adolescence. At present, the number of adolescent smokers, especially smoking girls, is growing worldwide. ${ }^{6}$

The lack of physical activity is increasing globally due to an easier access to cars, working conditions, technology and other determinants. During adolescence, new habits are acquired that lead to having an active lifestyle in the future, but youth are slowly losing incentives. ${ }^{7,8}$

Valid and reliable information is required for establishing and monitoring health promotion actions. ${ }^{9}$ For this purpose, periodic surveys are administered at secondary schools, usually to 13 to 15 year-old adolescents, since this is the period when risk behaviors usually start.

In this setting, the Global SchoolBased Student Health Survey (GSHS) and the Global Youth Tobacco Survey (GYTS), which have been promoted 
by the Ministry of Health and the Ministry of Education of Argentina, are basic tools for decision-making.

In 2001, the World Health Organization (WHO), the United Nations Children's Fund (UNICEF), the United Nations Educational, Scientific and Cultural Organization (UNESCO), the United Nations AIDS Agency (UNAIDS), and the US Centers for Disease Control and Prevention (CDC) developed the GSHS. It has been used in many countries since $2003,{ }^{10}$ and it was administered in $2007^{11}$ and 2012 in Argentina.

The GYTS is part of the Global Tobacco Surveillance System and was developed by the WHO, the CDC and the Canadian Public Health Association (CPHA). It has been implemented in more than 170 countries since $1999 .{ }^{12}$

In Argentina, the GYTS has been administered in the Autonomous City of Buenos Aires (2000, 2003, 2007 and 2012), in the province of Buenos Aires (2003, 2007 and 2012), and at a national level for the first time in $2007^{13}$ and 2012.

The purpose of this report is to describe the results of both surveys, administered simultaneously at a national level in November 2012 , and to compare the risk of noncommunicable diseases to that observed using the same surveys in $2007.14,15$

\section{POPULATION AND METHODS}

Design: Descriptive, cross-sectional and analytical study.

\section{Population}

Students aged between 13 and 15 years old attending first through third year at secondary schools in Argentina.

\section{Instruments}

The GSHS and the GYTS questionnaires were delivered to students. Both surveys included validated questionnaires with common basic questions and country-specific questions. Questions were translated into Spanish and transculturally adapted to Argentina. Surveys were self- administered. Each student completed an anonymous response grid delivered at the end of the class on the day of the survey.

Although the GSHS and the GYTS evaluate several aspects, this report includes only those related to diet, tobacco use and physical activity.

For the school setting assessment, the personnel of the survey completed a card of direct observation and key informants in each school were asked to complete a brief survey.

\section{Included Aspects and Definition of Outcome Measures}

A complete description of outcome measures and the rationale for their use can be found in different publications. ${ }^{10,12}$

\section{Diet and body weight:}

- Overweight prevalence: defined as a body mass index higher than 1 standard deviation for each age and gender group, according to the WHO's recommendations ${ }^{16}$ as per self-reported weight and height.

- Obesity prevalence: defined as a body mass index higher than 2 standard deviations for each age and gender group, according to the WHO's recommendations as per self-reported weight and height.

- Fruit and vegetable consumption (5 or more times per day in the past 30 days, including root vegetables).

- Carbonated soft drink consumption (2 or more times per day in the past 30 days).

- Fast food consumption (3 or more times every week in the past 30 days).

\section{Tobacco use:}

- Tobacco use prevalence: smoking, at least, one cigarette in the past 30 days.

- Prevalence of exposure to secondhand smoke in the past 7 days: at home and in places outside home.

- Proportion of current smokers who want to quit.

- Proportion of smokers who bought cigarettes in a store and were NOT refused the purchase because of their age in the past 30 days.

\section{Physical activity:}

- Proportion of physically active youth: more than 60 minutes per day in, at least, 5 days of the past 7 days.

- Proportion of youth who spent 3 or more hours sitting down in a typical day (usually).

- Proportion of youth who attended, at least, 3 physical education classes per week in the past school year.

- Proportion of youth who walked or rode a bicycle to or from school 1 or more times in the past 7 days.

\section{Sample Design}

The 2012 GSHS and GYTS used a two-stage sampling design to produce a representative national sample of first through third year secondary school students (from eighth grade in 
the Basic General Education through first year of polimodal school in the province of Buenos Aires). The GYTS was administered nationally, while the GSHS, at a national and provincial level.

The first sampling stage included all public and private secondary schools based on the Ministry of Education's census. Schools were selected with a likelihood proportional to the number of students. Six hundred schools were selected to take part in the GSHS (since it allows obtaining estimates per province) and 75 schools were selected for the GYTS.

Systematic sampling was performed in each school so as to select two or three classes per school. All students who attended school on the survey day were eligible to complete it.

A weighting factor was applied to expand the sample in agreement with the probabilities of selection for each stage and adjustment of the general population by age and gender, and nonresponse.

\section{Field Work and Administration of Surveys}

The field work of surveys was conducted between November and December 2012. Survey procedures were designed in order to protect students' privacy and warrant an anonymous, voluntary participation. Surveys were selfadministered.

\section{Evaluation of the School Setting}

A sub-sample made up of 250 schools was used to make observations within each school, such as aspects related to physical activity (number of class hours, extracurricular courses offered, facilities, etc.), tobacco use (traces of tobacco use in bathrooms, classrooms, halls, etc.), and food offered at the school's candy stand and/ or canteens.

\section{Statistical Analysis}

Prevalences were estimated for the overall population, males and females, and for 2007 and 2012, together with the corresponding 95\% confidence intervals considering the complex sample design used. Prevalences were compared between 2007 and 2012 using an independent, chisquare proportion comparison test, including the complex sample design.

Based on the school sub-sample, the proportion of schools that offered food and beverages, physical activity opportunities and facilities, and compliance with smoking bans at schools were reported.
$P$ values equal to or lower than 0.05 were statistically significant.

\section{Ethical Considerations}

The protocol was approved by an independent ethics committee in Argentina and by the Pan American Health Organization's Ethics Review Committee. Survey administration was authorized by the Ministry of Education, provincial ministries and school authorities. Responses were absolutely confidential and anonymized in unidentified answer sheets, which were collected at the end of the class. Students were asked to provide their oral consent before completing the self- administered survey.

\section{RESULTS}

For the GSHS, the response rate was $77 \%$ in 2007 (47 schools and 1498 students) and 71\% in 2012 (544 schools and 20697 students). In 2012, the school response was lower (91\% versus $94 \%$ ), and the individual response reduced $(73.4 \%$ versus $79 \%$ ).

For the GYTS, the response rate was $74 \%$ in 2007 (71 schools and 3421 students) and $76.9 \%$ in 2012 (73 schools and 2062 students).

Two hundred and thirty-two schools were included in the school setting assessment. Distribution by respondents' age and gender for the 2007 and 2012 samples is described in Table 1, and school and student participation in 2012 is shown in Figure 1.

\section{Diet}

In 2012,17.6\% of all respondents ate 5 servings of fruits and vegetables per day, which is a slight increase from the $14 \%$ in $2007(p=0.041)$.

In relation to sugar-sweetened beverages, $48.1 \%$ of all respondents had 2 or more per day, which is a small reduction from $2007(p=0.013)$.

No differences were observed between 2007 and 2012 in terms of fast food consumption (7.4\% in 2007 versus $6.8 \%$ in 2012) (see Table 2).

There was a candy stand in $80.2 \%$ of schools. Non-diet soft drinks were offered in $81.2 \%$, while only $24.7 \%$ offered fruits. Also, $91.4 \%$ of candy stands offered food, candies and beverages with a high calorie density, high in sodium, sugar and/or fat (for example, snacks, hamburgers and hot dogs, sugar-sweetened beverages, candies). There was no drinking water in the bathrooms of $90.9 \%$ of schools, although only $5.6 \%$ had drinking fountains or water dispensers. 
TABLE 1. Global School-Based Student Health Survey and Global Youth Tobacco Survey

Global School-Based Student Health Survey, 2007 and 2012: sample by age and gender

\begin{tabular}{llcc}
\hline Year & & 2007 & $\mathbf{2 0 1 2}$ \\
\hline Groups & & \multicolumn{2}{c}{ Frequency } \\
\hline Gender & Male & 705 & 9671 \\
& Female & 793 & 11026 \\
\multirow{2}{*}{ Age } & 13 years old & 333 & 4951 \\
& 14 years old & 595 & 8091 \\
& 15 years old & 570 & 7655 \\
\hline
\end{tabular}

Global Youth Tobacco Survey, 2007 and 2012: sample by age and gender

\begin{tabular}{llcc}
\hline Year & & 2007 & 2012 \\
\hline Groups & & \multicolumn{2}{c}{ Frequency } \\
\hline Gender & Male & 1612 & 1016 \\
& Female & 1809 & 1046 \\
Age & 13 years old & 765 & 594 \\
& 14 years old & 1303 & 812 \\
& 15 years old & 1353 & 656 \\
\hline
\end{tabular}

\section{Overweight and Obesity}

Overweight prevalence increased from $24.5 \%$ in 2007 to $28.6 \%$ in 2012 ( $p=0.025)$, with a higher prevalence among boys in both years surveyed. In $2012,5.9 \%$ of respondents were obese $(8.3 \%$ in boys and $3.6 \%$ in girls), which is a significant increase from $4.4 \%$ in $2007(p=0.05)$. Similar increases were observed both in males and females (Table 2).

\section{Physical Activity}

Only $21.2 \%$ of boys, $12.4 \%$ of girls and $16.7 \%$ of all respondents were physically active, which is slightly higher than the $12.7 \%$ of physically active participants observed in 2007 ( $p=0.014)$.

There were no changes in the proportion of youth who spent 3 or more hours sitting down per day ( $49.2 \%$ in 2007 versus $50.3 \%$ in 2012) or in the proportion of youth who used an active means of transport to or from the school $(74.3 \%$ in 2007 versus $68.8 \%$ in 2012).

Figure 1. Flow chart of participants for the Global School-Based Student Health Survey, 2012, and the Global Youth Tobacco Survey, 2012

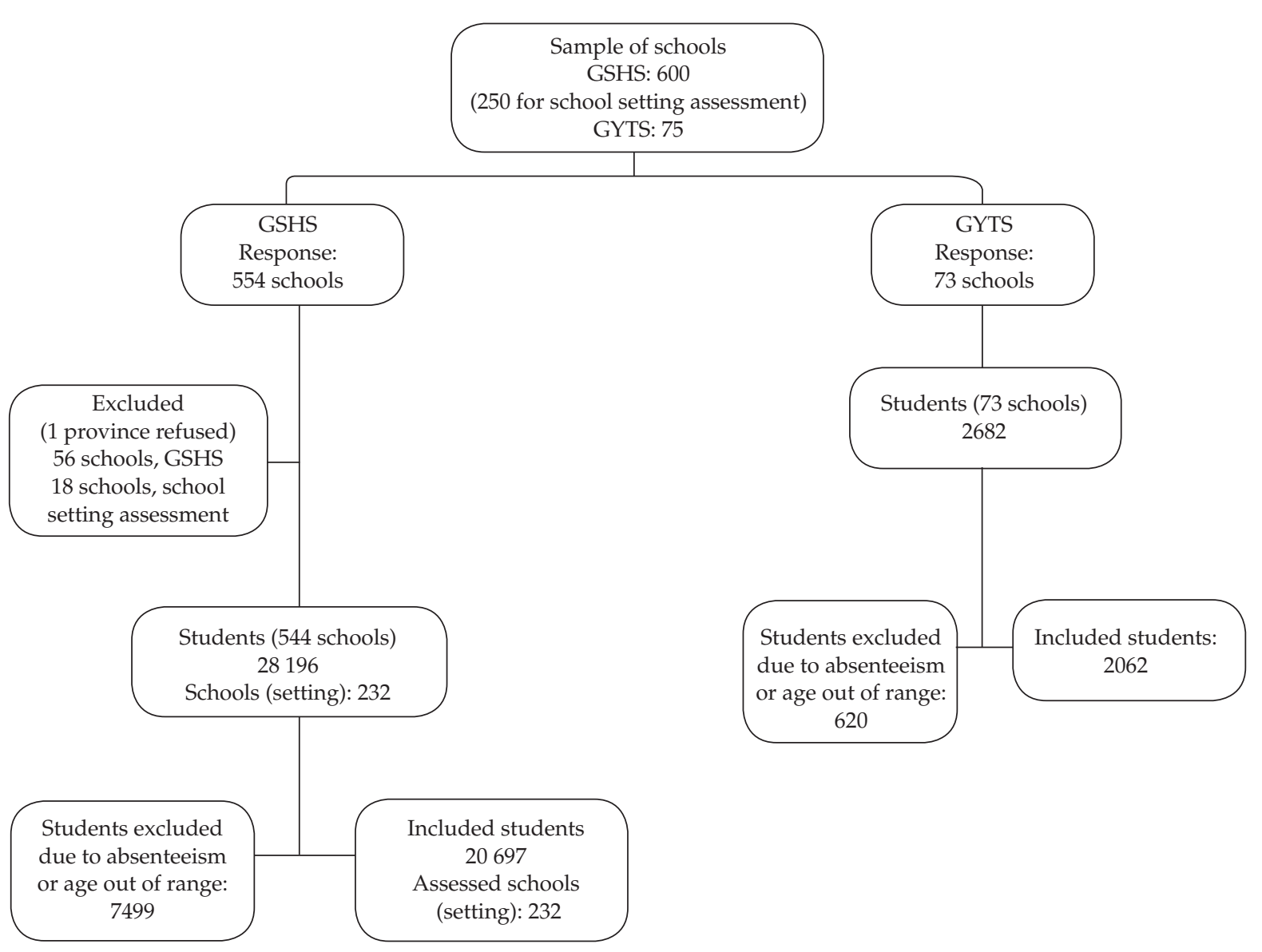


Between 2007 and 2012, the proportion of youth who reported their school offered 3 or more physical education classes per week increased from $18.8 \%$ to $25.9 \%$ ( $p=0.005$ ) (Table 3).

Regarding the survey of schools, $69 \%$ had their own facilities for physical activity and $49 \%$ offered extracurricular activities.

\section{Tobacco Use}

A significant reduction was observed in the prevalence of tobacco use (cigarettes), from $24.5 \%$ to $19.6 \%(p=0.015)$, with a higher use among girls in both years surveyed $(p=0.002)$. A higher proportion of young smokers quitted (50.2\% in 2007 versus $55.2 \%$ in 2012). Exposure to secondhand smoke was reduced at the expense of exposure at home $(54.7 \%$ in 2007 versus $47.5 \%$ in $2012, p=0.007)$. Most youth who bought cigarettes in a store were not refused the purchase, with no significant changes in the evaluated period $(88.7 \%$ in 2007 versus $81.5 \%$ in 2012) (Table 4).

Based on observation, there were traces of cigarette smoking in $24.6 \%$ of schools. Only $27.6 \%$ of schools displayed no smoking signs.

\section{DISCUSSION}

These surveys were administered nationwide in 2012 and show an increase in overweight and obesity, a somewhat lower, but persistently high, consumption of fast food and sugar-sweetened beverages, and a low consumption of fruits and vegetables. In 2005, although in a different population, the National Survey on Nutrition and Health in Argentina reported a prevalence of obesity of $4.4 \%$ in children younger than 5 years old and of $15.3 \%$ in women aged 10 to 49 years old.

Overweight and obesity have increased in spite of the mild improvements observed in dietary patterns, which are far from those recommended.

In the past years, these have contributed to generate an obesogenic environment, probably due to a higher consumption of high calorie density food and a low level of physical activity, which remains low in spite of its small increase. Although there was a scarce reduction in the consumption of sugar-sweetened beverages, they still play a major source of calorie intake in this group.

The number of physically active adolescents increased, although it is still low for what is recommended at this age. The offer of physical education classes increased, but this tool does not allow to assess their intensity or quality.

Tobacco use prevalence was significantly reduced, but a greater consumption persisted among girls. The proportion of youth smokers who want to quit increased. Although exposure to secondhand smoke was significantly reduced, it is still high. Access to tobacco products is still in the high range. The ban on tobacco products advertising and sponsoring (although sales

TABLE 2. Global School-Based Student Health Survey, diet and body weight, 2007-2012

\begin{tabular}{|c|c|c|c|c|c|c|c|}
\hline \multirow{3}{*}{$\begin{array}{l}\text { Diet and } \\
\text { body weight }\end{array}$} & \multicolumn{3}{|c|}{2007} & \multicolumn{3}{|c|}{2012} & \multirow{3}{*}{$\begin{array}{c}2007-2012 \\
P^{*}\end{array}$} \\
\hline & \multirow[t]{2}{*}{ Total } & \multicolumn{2}{|c|}{ Gender } & \multirow[t]{2}{*}{ Total } & \multicolumn{2}{|c|}{ Gender } & \\
\hline & & Male & Female & & Male & Female & \\
\hline $\begin{array}{l}\text { Fruit and vegetable } \\
\text { consumption } 5 \text { or } \\
\text { more times per } \\
\text { day (past } 30 \text { days) }\end{array}$ & $\begin{array}{c}14.0 \% \\
(11.0 \%-17.7 \%)\end{array}$ & $\begin{array}{c}13.6 \% \\
(10.2 \%-18.0 \%)\end{array}$ & $\begin{array}{c}14.4 \% \\
(10.9 \%-18.7 \%)\end{array}$ & $\begin{array}{c}17.6 \% \\
(16.2 \%-19.1 \%)\end{array}$ & $\begin{array}{c}16.6 \% \\
(14.9 \%-18.4 \%)\end{array}$ & $\begin{array}{c}18.6 \% \\
(17.0 \%-20.4 \%)\end{array}$ & 0.041 \\
\hline $\begin{array}{l}\text { Sugar-sweetened } \\
\text { beverage consumptior } \\
2 \text { or more times per } \\
\text { day (past } 30 \text { days) }\end{array}$ & $\begin{array}{c}52.6 \% \\
\text { on }(48.9 \%-56.3 \%\end{array}$ & $\begin{array}{c}50.5 \% \\
(46.2 \%-54.8 \%)\end{array}$ & $\begin{array}{c}54.5 \% \\
(49.0 \%-59.9 \%)\end{array}$ & $\begin{array}{c}48.1 \% \\
(46.0 \%-50.2 \%)\end{array}$ & $\begin{array}{c}54.0 \% \\
(50.5 \%-57.5 \%)\end{array}$ & $\begin{array}{c}49.8 \% \\
(47.5 \%-52.1 \%)\end{array}$ & 0.013 \\
\hline $\begin{array}{l}\text { Eating at fast food } \\
\text { restaurants on } \\
3 \text { or more days } \\
\text { (past } 7 \text { days) }\end{array}$ & $\begin{array}{c}7.4 \% \\
(4.7 \%-11.4 \%)\end{array}$ & $\begin{array}{c}7.0 \% \\
(4.2 \%-11.5 \%)\end{array}$ & $\begin{array}{c}7.3 \% \\
(4.5 \%-11.6 \%)\end{array}$ & $\begin{array}{c}6.8 \% \\
(5.8 \%-7.9 \%)\end{array}$ & $\begin{array}{c}7.0 \% \\
(5.4 \%-9.2 \%)\end{array}$ & $\begin{array}{c}6.6 \% \\
(5.8 \%-7.4 \%)\end{array}$ & 0.367 \\
\hline Overweight & $\begin{array}{c}24.5 \% \\
(21.6 \%-28.1 \%)\end{array}$ & $\begin{array}{c}32.4 \% \\
(29.0 \%-36.0 \%)\end{array}$ & $\begin{array}{c}17.6 \% \\
(13.9 \%-23.0 \%)\end{array}$ & $\begin{array}{c}28.6 \% \\
(26.8 \%-30.4 \%)\end{array}$ & $\begin{array}{c}35.9 \% \\
(33.4 \%-38.4 \%)\end{array}$ & $\begin{array}{c}21.8 \% \\
(19.7 \%-24.1 \%)\end{array}$ & 0.025 \\
\hline Obesity & $\begin{array}{c}4.4 \% \\
(3.2 \%-6.1 \%)\end{array}$ & $\begin{array}{c}6.5 \% \\
(4.5 \%-9.3 \%)\end{array}$ & $\begin{array}{c}2.6 \% \\
(1.3 \%-5.2 \%)\end{array}$ & $\begin{array}{c}5.9 \% \\
(5.1 \%-6.8 \%)\end{array}$ & $\begin{array}{c}8.3 \% \\
(7.1 \%-9.8 \%)\end{array}$ & $\begin{array}{c}3.6 \% \\
(2.8 \%-4.7 \%)\end{array}$ & 0.050 \\
\hline
\end{tabular}

* Indicates the comparison between the total for 2007 and the total for 2012. 
locations still display tobacco advertising), provincial and national smoke-free regulations, and the emergence of graphic health warnings may also account for such reduction. However, the fact that cigarettes continue to be sold at low prices leads to youth having easy access to them, also considering that bans on cigarette sale to minors have not been effective. In addition to the consolidation of current actions, it is necessary to increase cigarette prices, which is especially useful to reduce tobacco use in this population. ${ }^{17}$
At present, in Argentina cigarettes are sold at the lowest price in the region adjusted as per the national purchasing power. ${ }^{18}$

In relation to overweight and obesity, the National Obesity Guide has been launched recently. ${ }^{19}$

Initiatives towards the promotion of a healthy diet targeted at this population and school setting have been implemented in Argentina through healthy candy stands and canteens. Changes should be deepened at a population level, both

TABLE 3. Global School-Based Student Health Survey, physical activity, 2007-2012

\begin{tabular}{|c|c|c|c|c|c|c|c|}
\hline \multirow{3}{*}{$\begin{array}{l}\text { Physical } \\
\text { activity }\end{array}$} & \multicolumn{3}{|c|}{2007} & \multicolumn{3}{|c|}{2012} & \multirow{3}{*}{$\begin{array}{c}2007-2012 \\
P^{*}\end{array}$} \\
\hline & \multirow[t]{2}{*}{ Total } & \multicolumn{2}{|c|}{ Gender } & \multirow[t]{2}{*}{ Total } & \multicolumn{2}{|c|}{ Gender } & \\
\hline & & Male & Female & & Male & Female & \\
\hline $\begin{array}{l}\text { Physically active for, } \\
\text { at least, } 60 \text { minutes } \\
\text { per day (past } 7 \text { days) }\end{array}$ & $\begin{array}{c}12.7 \% \\
(9.8 \%-16.3 \%)\end{array}$ & $\begin{array}{c}18.2 \% \\
(13.5 \%-24.2 \%)\end{array}$ & $\begin{array}{c}7.9 \% \\
(5.6 \%-11.2 \%)\end{array}$ & $\begin{array}{c}16.7 \% \\
(15.8 \%-17.7 \%)\end{array}$ & $\begin{array}{c}21.2 \% \\
(20.0 \%-22.6 \%)\end{array}$ & $\begin{array}{c}12.4 \% \\
(11.3 \%-13.7 \%)\end{array}$ & 0.014 \\
\hline $\begin{array}{l}\text { Spent } 3 \text { or more hours } \\
\text { sitting down (on a } \\
\text { typical or usual day) }\end{array}$ & $\begin{array}{c}49.2 \% \\
(41.6 \%-56.8 \%)\end{array}$ & $\begin{array}{c}44.0 \% \\
(37.1 \%-51.1 \%)\end{array}$ & $\begin{array}{c}53.9 \% \\
(44.4 \%-63.1 \%)\end{array}$ & $\begin{array}{c}50.3 \% \\
(48.6 \%-52.0 \%)\end{array}$ & $\begin{array}{c}47.1 \% \\
(44.3 \%-49.9 \%)\end{array}$ & $\begin{array}{c}53.4 \% \\
(51.1 \%-55.7 \%)\end{array}$ & 0.384 \\
\hline $\begin{array}{l}\text { More than } 3 \text { classes } \\
\text { per week }\end{array}$ & $\begin{array}{c}18.2 \% \\
(13.6 \%-22.7 \%)\end{array}$ & $\begin{array}{c}19.5 \% \\
(14.3 \%-24.7 \%)\end{array}$ & $\begin{array}{c}16.9 \% \\
(12 \%-21.9 \%)\end{array}$ & $\begin{array}{c}25.9 \% \\
(23.9 \%-28.0 \%)\end{array}$ & $\begin{array}{c}28.6 \% \\
(25.5 \%-32.0 \%)\end{array}$ & $\begin{array}{c}23.3 \% \\
(21.8 \%-24.9 \%)\end{array}$ & 0.005 \\
\hline $\begin{array}{l}\text { Active transport } \\
\text { to or from school } \\
1 \text { or more times per week } \\
\text { (past } 7 \text { days) }\end{array}$ & $\begin{array}{c}74.3 \% \\
(67.4 \%-80.2 \%)\end{array}$ & $\begin{array}{c}73.3 \% \\
(66.9 \%-78.8 \%)\end{array}$ & $\begin{array}{c}75.3 \% \\
(67.4 \%-81.8 \%)\end{array}$ & $\begin{array}{c}68.8 \% \\
(66.0 \%-71.5 \%)\end{array}$ & $\begin{array}{c}69.1 \% \\
(65.9 \%-72.2 \%)\end{array}$ & $\begin{array}{c}68.5 \% \\
(65.6 \%-71.3 \%)\end{array}$ & 0.255 \\
\hline
\end{tabular}

* Indicates the comparison between the total for 2007 and the total for 2012.

TABLE 4. Global Youth Tobacco Survey, tobacco use, 2007-2012

\begin{tabular}{|c|c|c|c|c|c|c|c|}
\hline \multirow[t]{3}{*}{ Tobacco use } & \multicolumn{3}{|c|}{2007} & \multicolumn{3}{|c|}{2012} & \multirow{3}{*}{$\begin{array}{c}2007-2012 \\
P^{*}\end{array}$} \\
\hline & \multirow[t]{2}{*}{ Total } & \multicolumn{2}{|c|}{ Gender } & \multirow[t]{2}{*}{ Total } & \multicolumn{2}{|c|}{ Gender } & \\
\hline & & Male & Female & & Male & Female & \\
\hline $\begin{array}{l}\text { Percentage of youth } \\
\text { who currently smoke }\end{array}$ & $\begin{array}{c}24.5 \% \\
(22.2 \%-27 \%)\end{array}$ & $\begin{array}{c}21.1 \% \\
(18.5 \%-23.8 \%)\end{array}$ & $\begin{array}{c}27.3 \% \\
(23.4 \%-31.6 \%)\end{array}$ & $\begin{array}{c}19.6 \% \\
(16.4 \%-23.3 \%)\end{array}$ & $\begin{array}{c}17.4 \% \\
(14.7 \%-20.5 \%)\end{array}$ & $\begin{array}{c}21.5 \% \\
(17.1 \%-26.7 \%)\end{array}$ & 0.015 \\
\hline $\begin{array}{l}\text { Want to quit } \\
\text { smoking now }\end{array}$ & $\begin{array}{c}50.2 \% \\
(44.1 \%-56.2 \%)\end{array}$ & $\begin{array}{c}47.3 \% \\
(38 \%-56.9 \%)\end{array}$ & $\begin{array}{c}52.3 \% \\
(45.7 \%-58.9 \%)\end{array}$ & $\begin{array}{c}55.2 \% \\
(44.7 \%-65.3 \%)\end{array}$ & $\begin{array}{c}57.8 \% \\
(44.9 \%-69.7 \%)\end{array}$ & $\begin{array}{c}53.1 \% \\
(38.4 \%-67.3 \%)\end{array}$ & 0.420 \\
\hline $\begin{array}{l}\text { Current smokers who } \\
\text { bought cigarettes in a } \\
\text { store and were not } \\
\text { refused the purchase } \\
\text { because of their age in } \\
\text { the past } 30 \text { days }\end{array}$ & $\begin{array}{c}88.7 \% \\
(83.1 \%-92.6 \%)\end{array}$ & $\begin{array}{c}86.4 \% \\
(75.4 \%-93.0 \%)\end{array}$ & $\begin{array}{c}90.9 \% \\
(84.0 \%-95.0 \%)\end{array}$ & $\begin{array}{c}81.5 \% \\
(72.7 \%-88.0 \%)\end{array}$ & $\begin{array}{c}79.3 \% \\
(68.1 \%-87.3 \%)\end{array}$ & $\begin{array}{c}82.9 \% \\
(72.7 \%-89.8 \%)\end{array}$ & o) 0.176 \\
\hline $\begin{array}{l}\text { Exposure to secondhand } \\
\text { smoke at home }\end{array}$ & $\begin{array}{c}54.7 \% \\
(51.9 \%-57.4 \%)\end{array}$ & $\begin{array}{c}51.2 \% \\
(48.3 \%-55.2 \%)\end{array}$ & $\begin{array}{c}57.7 \% \\
(54.4 \%-61.0 \%)\end{array}$ & $\begin{array}{c}47.5 \% \\
(43.1 \%-51.9 \%)\end{array}$ & $\begin{array}{c}44.5 \% \\
(39.7 \%-49.4 \%)\end{array}$ & $\begin{array}{c}50.1 \% \\
(44.6 \%-55.7 \%)\end{array}$ & 0.007 \\
\hline $\begin{array}{l}\text { Exposure to secondhand } \\
\text { smoke outside home }\end{array}$ & $\begin{array}{c}68.6 \% \\
(65.9 \%-71.1 \%)\end{array}$ & $\begin{array}{c}66.4 \% \\
(63.2 \%-69.5 \%)\end{array}$ & $\begin{array}{c}70.7 \% \\
(66.9 \%-74.2 \%)\end{array}$ & $\begin{array}{c}69.4 \% \\
(65.7 \%-72.9 \%)\end{array}$ & $\begin{array}{c}64.2 \% \\
(60.0 \%-68.2 \%)\end{array}$ & $\begin{array}{c}74.3 \% \\
(69.4 \%-78.6 \%)\end{array}$ & 0.732 \\
\hline
\end{tabular}

* Indicates the comparison between the total for 2007 and the total for 2012. 
in terms of demand (such as nutrition education strategies, ${ }^{20,21}$ food marketing regulation, ${ }^{22}$ nutrition labeling modifications) ${ }^{23}$ and offer (for example, regulation of food nutritional content, such as sodium, ${ }^{24}$ trans fats, ${ }^{25}$ and sugar, tax policies, ${ }^{26,27}$ and serving sizes) so as to promote a healthier diet.

With regard to physical activity, there is consistent evidence in relation to increasing the number of hours and intensity of physical education offered at schools, ${ }^{28}$ promoting extracurricular activities at schools and communication actions, ${ }^{29}$ a higher access to physical activity offered in the community, ${ }^{30}$ and more access to adequate public facilities for physical activity, and modifications of the urban environment and promotion of public and active transportation. ${ }^{31}$

Limitations include the fact that this was a self-reporting assessment instead of a direct measurement of body weight and height, and that the response rate was lower than expected for the GSHS because one of the jurisdictions refused to participate in the surveys and given the absenteeism rate in some schools. The strength of these surveys is that they use validated questionnaires, probabilistic sampling and a sustained methodology that allows assessing progress over time.

Argentina is no stranger to the overweight and obesity epidemic and the sedentary lifestyle that are especially affecting developing countries. Consolidating health promotion actions, both at a community and educational level, is critical to finally start bending this trend. In spite of improvements in tobacco use, it is necessary to strengthen current current policies related to pricing, smoke-free environment and advertising.

\section{CONCLUSION}

The main results obtained with these surveys suggest that tobacco use has been reduced, but exposure to secondhand smoke is still high; overweight and obesity prevalence is increasing; and no significant improvements have been observed in relation to physical activity and a healthy diet.

\section{REFERENCES}

1. World Health Organization: Adolescents: health risks and solutions. Fact sheet $\mathrm{N}^{\circ} 345$. Geneva: $\mathrm{WHO} ; 2014$. Available at: http://www.who.int/mediacentre/factsheets/fs345/ en/index.html. [Accessed on: March 3, 2014].

2. Gore FM, Bloem DJ, Patton GC, Ferguson J, et al. Global burden of disease in young people aged 10-24 years: a systematic analysis. Lancet 2011;377(9783):2093-102.
3. Secretaría de Políticas, Regulación e Institutos. Dirección de Estadísticas e Información de Salud. Estadísticas vitales. Información básica año 2012. Buenos Aires: Ministerio de Salud de la Nación; 2013. Available at: http:/ / www.deis. gov.ar/Publicaciones/Archivos/Serie5Nro56.pdf. [Accessed on: March 3, 2014].

4. Lim SS, Vos T, Flaxman AD, Danaei G, et al. A comparative risk assessment of burden of disease and injury attributable to 67 risk factors and risk factor clusters in 21 regions, 1990-2010: a systematic analysis for the Global Burden of Disease Study 2010. Lancet 2012;380(9859):2224-60.

5. McAllister EJ, Dhurandhar NV, Keith SW, Aronne LJ, et al. Ten putative contributors to the obesity epidemic. Crit Rev Food Sci Nutr 2009;49(10):868-913.

6. Warren CW, Jones NR, Eriksen MP, Asma S, et al. Patterns of global tobacco use in young people and implications for future chronic disease burden in adults. Lancet 2006;367(9512):749-53.

7. Bauman AE, Reis RS, Sallis JF, Wells JC, et al. Correlates of physical activity: why are some people physically active and others not? Lancet 2012;380(9838):258-71.

8. Sixty-fourth World Health Assembly. Youth and health risks. WHA64.28.Geneva:World Health Organization;2011. Availableat:http://apps.who.int/gb/ebwha/pdf_files/WHA64/ A64_R28-en.pdf. [Accessed on: March 3, 2014].

9. Argentina. Ministerio de Salud de la Nación. Estrategia Nacional para la Prevención y Control de Enfermedades No Transmisibles. Buenos Aires: Ministerio de Salud de la Nación; 2009. Available at: http://www.msal.gov.ar/ images/stories/bes/graficos/0000000203cnt-2013-07_estrategia-nacional-prevencion-control-ent-as.pdf. [Accessed on: March 3, 2014].

10. World Health Organization. Global school-based student health survey (GSHS) purpose and methodoloy. Geneva: WHO;2014. Available at: http://www.who.int/chp/gshs/ methodology/en/. [Accessed on: March 3, 2014].

11. Linetzky B, Morello P, Virgolini M, Ferrante D. Resultados de la Primera Encuesta Nacional de Salud Escolar. Argentina, 2007. Arch Argent Pediatr 2011;109(2):111-6.

12. Centers of Disease Control and Prevention. Global Youth Tobacco Survey (GYTS)-Overview. Atlanta: CDC; 2014. Available at: http://nccd.cdc.gov/gtssdata/Ancillary/ Documentation.aspx?SUID=1\&DOCT $=1$. [Accessed on: 3 de marzo de 2014].

13. Linetzky B, Mejia R, Ferrante D, De Maio FG, et al. Socioeconomic status and tobacco consumption among adolescents: a multilevel analysis of Argentina's Global Youth Tobacco Survey. Nicotine Tob Res 2012;14(9):1092-9.

14. Argentina. Ministerio de Salud de la Nación. Encuesta Mundial de Salud Escolar. Resultados de 2007. Argentina. Buenos Aires, 2008. [Accessed on: 4 de marzo de 2014]. Available at: http://www.msal.gov.ar/ent/images/ stories/vigilancia/pdf/encuesta_mundial_salud_ escolar_2007.pdf.

15. Argentina. Ministerio de Salud de la Nación. Encuesta Mundial de Tabaquismo en Adolescentes en Argentina. Resultados de 2007 y comparación con encuestas previas. Argentina. Buenos Aires, 2009. [Accessed on: 4 de marzo de 2014]. Available at: http://www.msal.gov.ar/ent/ images/stories/vigilancia/pdf/encuesta_tabaquismo_ adolescentes_2007.pdf.

16. World Health Organization. Grouth reference 5-19 years. BMI-for-age (5-19 years). Geneva: WHO; 2007. Available at: http://www.who.int/growthref/who2007_bmi_for_ age/en/. [Accessed on: 3 de marzo de 2014].

17. Martínez E, Mejia R, Pérez-Stable EJ. An empirical analysis of cigarette demand in Argentina. Tob Control 2013. Publicación electrónica 12 de junio de 2013. [En prensa]. 
18. Konfino J, Ondarsuhu D, Goldberg L, Linetzky B, et al. Encuesta mundial de tabaquismo en adultos 2012: resultados de la primera implementación en Argentina. Rev Argent Salud Publ 2013;4(16):6-15.

19. Argentina. Ministerio de Salud de la Nación. Guía de Práctica Clínica Nacional sobre Diagnóstico y Tratamiento de la Obesidad. Buenos Aires: Ministerio de Salud de la Nación; 2013. Available at: http://www.msal.gov.ar/ ent/images/stories/equipos-salud/pdf/2014-05_gpc_ obesidad.pdf. [Accessed on: 3 de marzo de 2014].

20. Thorogood M, Simera I, Dowler E, Summerbell C, et al. A systematic review of population and community dietary interventions to prevent cancer. Nutr Res Rev 2007;20(1):7488.

21. Wakefield MA, Loken B, Hornik RC. Use of mass media campaigns to change health behaviour. Lancet 2010;376(9748):1261-71.

22. Organización Mundial de la Salud. Conjunto de recomendaciones sobre la promoción de alimentos y bebidas no alcohólicas dirigida a los niños. Ginebra: OMS; 2010. Available at: http://whqlibdoc.who. int/publications / 2010/9789243500218_spa.pdf?ua=1. [Accessed on: 3 de marzo de 2014].

23. Campos S, Doxey J, Hammond D. Nutrition labels on prepackaged foods: a systematic review. Public Health Nutr 2011;14(8):1496-506.

24. Ferrante D, Konfino J, Mejía R, Coxson P, et al. Relación costo-utilidad de la disminución del consumo de sal y su efecto en la incidencia de enfermedades cardiovasculares en Argentina. Rev Panam Salud Publica 2012;32(4):274-80.
25. Argentina. Ministerio de Salud de la Nación. Campaña "Argentina 2014 Libre de Grasas Trans". Buenos Aires: Ministerio deSalud dela Nación;2014. Availableat: http:/ / www.msal.gov.ar/ent/index.php?option=com_content\& view $=$ article\&id=348: campana-qargentina-2014-libre-degrasas-trans\&catid=9. [Accessed on: 3 de marzo de 2014].

26. Maniadakis N, Kapaki V, Damianidi L, Kourlaba G. A systematic review of the effectiveness of taxes on nonalcoholic beverages and high-in-fat foods as a means to prevent obesity trends. Clinicoecon Outcomes Res 2013;5:51943.

27. Powell LM, Chriqui JF, Khan T, Wada R, et al. Assessing the potential effectiveness of food and beverage taxes and subsidies for improving public health: a systematic review of prices, demand and body weight outcomes. Obes Rev 2013;14(2):110-28.

28. Lonsdale C, Rosenkranz RR, Peralta LR, Bennie A, et al. A systematic review and meta-analysis of interventions designed to increase moderate-to-vigorous physical activity in school physical education lessons. Prev Med 2013;56(2):152-61.

29. Kahn EB, Ramsey LT, Brownson R, Heth GW, et al. The effectiveness of interventions to increase physical activity: a systematic review. Am J Prev Med 2002;22(4 Suppl):73-107.

30. Increasing physical activity. A report on recommendations of the Task Force on Community Preventive Services. MMWR Recomm Rep 2001;50(RR-18):1-14.

31. Heath GW, Brownson RC, Kruger J, Miles R, et al. The effectiveness of urban design and land use and transport policies and practices to increase physical activity: a systematic review. J Phys Act Health 2006;3 (Suppl1):S55-S76. 